\title{
Assessing changes in seawater intrusion and water quality of the Shatt Al-Arab River, Iraq
}

\author{
H.A. Hameed*, M.H. Ali, Y.S. Aljorany, W.F. Hassan and A.A.Z.N. Al-Hello \\ Department of Marine Chemistry, Marine Science Center, University of Basrah, Basrah, Iraq
}

Received 1 March 2013; Accepted 27 June 2013

\begin{abstract}
Many adverse environmental factors influencing the Shatt-al Arab River, southern Iraq, during the past century and especially in recent years, combined with the ever-increasing demand for freshwater in the region, indicate the need to obtain information about its salinity regime. The aim of our study was both to find out what historical data there are and then to compare these with the results of a survey of the salinity and water quality of a stretch of the present river over the year October 2009-September 2010. The evidence suggests that there has been a marked upstream shift in the influence of sea water. Salinity values of 2 and $8 \%$ were found at two sites where elevated salinity had never been reported previously. Water quality variables indicated increased concentrations over the previous four decades and were beyond the national and international standards. As such changes in a major water resource have serious implications for the inhabitants of Basrah, the biological diversity in the river and the whole Gulf ecosystem, it is suggested that there should be a much more detailed study to provide the evidence needed to convince upstream water users of the need to conserve water and manage the whole catchment properly.
\end{abstract}

Key words: Seawater intrusion / water quality / monitoring / Shatt Al-Arab river / water management

\section{Introduction}

Human impacts on freshwater ecosystems pose an ever-increasing challenge to maintain the quality and quantity of water. For instance, climate change is expected to account for $20 \%$ of the global increase in water scarcity (FAO, 2007) by the end of this century. In southern Iraq, the Shatt Al-Arab poses a particular problem. It is formed by the confluence of the Tigris and Euphrates Rivers at Basrah, so water discharge and quality of the river is inevitably affected by any alteration in their catchments upstream, which include four different countries. Turkey contributes about 90 and $38 \%$, respectively, of the total annual flow of the Euphrates and Tigris Rivers, whereas the remainder comes largely from three tributaries originating in Iran; in Syria there are only very minor inputs to the Euphrates. The major part of the flow of both rivers is during spring, with flow becoming reduced to $10 \%$ of the mean annual discharge during summer (FAO, 2008). Construction of dams in turkey and reduced flow from Iran has led to progression of sea water upstream the Shatt Al-Arab and salinity problem present real threat to Basrah city. The Gulf now receives most of the contaminants

*Corresponding author: habbas_53@hotmail.com discharged into the Tigris-Euphrates basin through the Shatt Al-Arab, whereas more used to be filtered in the Mesopotamian Marshlands (Partow, 2001).

Irrigation runoff and untreated municipal and industrial wastes discharged directly into the rivers (Naff and Hanna, 2003) are the main factors influencing the quality of the Tigris and Euphrates. These in turn affect the quality of water in the Shatt Al-Arab. The available data suggest a decline in water quality as the tributaries enter Iraq and in the Shatt Al-Arab. Total dissolved solids (TDS) concentrations have increased downstream of the border of Syria-Iraq from $710 \mathrm{mg} . \mathrm{L}^{-1}$ in 1973 to $1100 \mathrm{mg} . \mathrm{L}^{-1}$ in 2002, whereas in the southern part of the country TDS increased from $1300 \mathrm{mg} . \mathrm{L}^{-1}$ in 1979 to $4500 \mathrm{mg} . \mathrm{L}^{-1}$ in 2001 (Rahi and Halihan, 2010). In the case of the Shatt Al-Arab, the mean TDS values of 1508 and $1691 \mathrm{mg} . \mathrm{L}^{-1}$ for 2006 and 2007, respectively, were reported at an upstream station (near station 4, Fig. 1) (Al-Mahmood, 2009). Whereas salinity values $<2 \%$ were reported regularly at downstream stations during the 1970s and 1980s. Al-Asadi et al. (2006) reported 2.1\%o at a station downstream of Basrah in 2006.

Studies have been conducted on the ecology of the Shatt Al-Arab and its side channels since the 1970s, although most were restricted to one or a few sites 


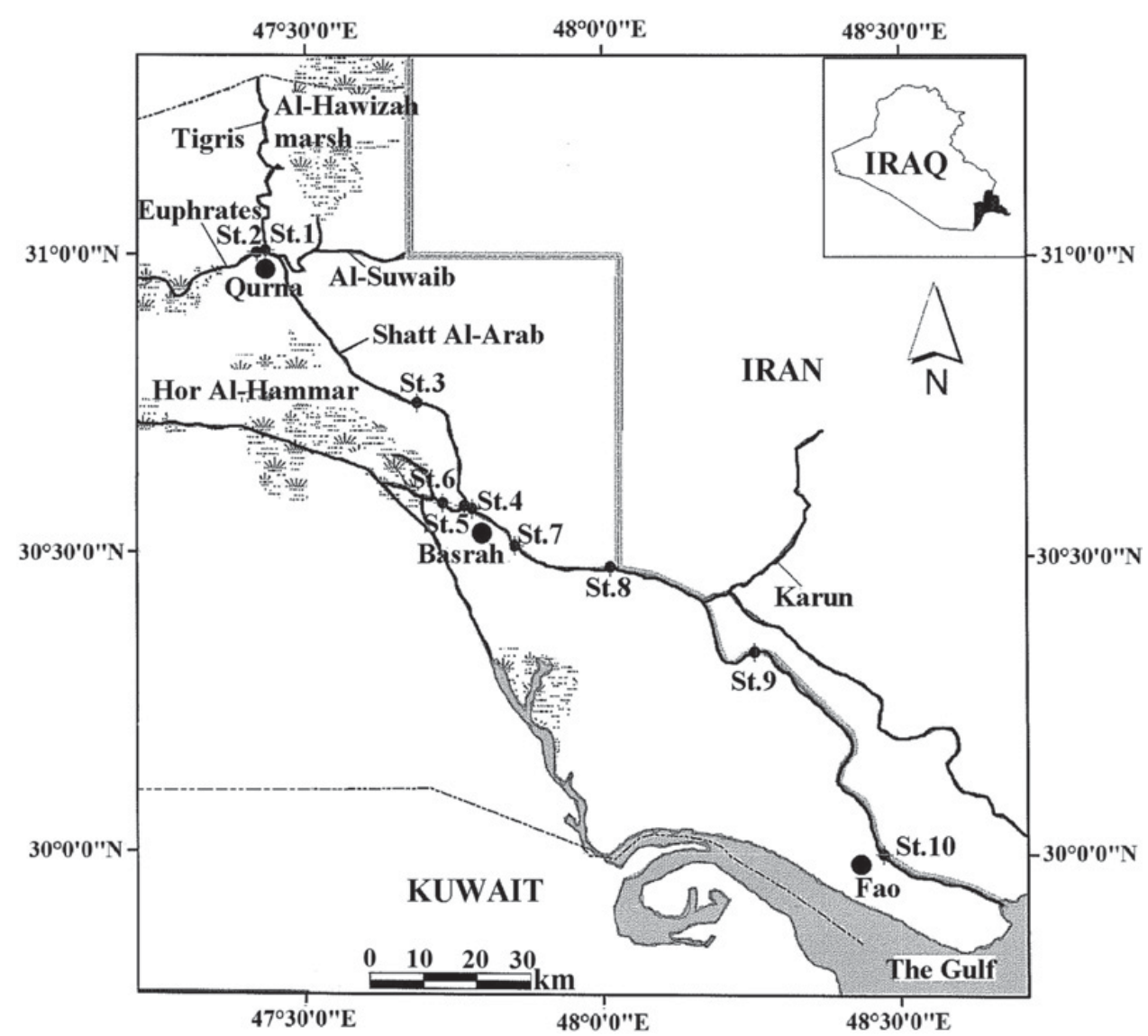

Fig. 1. Map of the Shatt Al-Arab.

(Huq et al., 1978; Massoud et al., 1978; Fawzi et al., 1990; Al-Hello, 2001; Al-Essa, 2004) or infrequent sample dates (Al-Mousawi et al., 1990; Karim, 1998; Mahmood, 2008). The most detailed earlier study was that of Al-Aubaidy and Al-Hello (1996), who collected monthly samples from eight stations between August 1991 and August 1992, and concluded that TDS concentrations increased on passing down the upper stretch of the Shatt Al-Arab, but then decreased due to dilution by the inflow of the Karun River.

The lack of any comprehensive study of the Shatt Al-Arab, in spite of its importance for the third largest city in Iraq and the Gulf ecosystem as a whole, shows the need to find out more about possible changes, especially in salinity, which might indicate an upstream shift in the influence of seawater. The aim of the present study was to survey the spatial and temporal changes in water quality over 1 year and to assess them against the historic record.

\section{Study area}

Basrah belongs to one of the four agro-ecological zones that stretch between the Tigris and Euphrates from north of Baghdad to Basrah in the south (FAO, 2003). The climate is subtropical semi-arid and the main annual rainfall is $<100 \mathrm{~mm}$, this occurring during December to February. Irrigation in Basrah is mostly dependent on surface water and the area of irrigated land in the Shatt Al-Arab basin is 105000 ha. The water-table in most of the irrigated land is close to the surface of the soil and is saline. Basrah is the last densely populated city on the waterway after the convergence of the Tigris and the Euphrates (Fig. 1). The main river combines providing transport lanes for the movement of bulk cargo and oil with the supply of water for municipal purposes and for irrigation. A number of drinking water treatment facilities are situated along the river.

Water from the Hor Al-Hammar (Mesopotamian Marshland) joins the Shatt Al-Arab near station 4 (Fig. 1). This originates both from the Euphrates via several streams and the Tigris through the Central Marshland, the water being discharged first into the Garmat Ali River (close to station 6) and eventually the Shatt Al-Arab near station 4 (Fig. 1). A total of $193 \mathrm{~km}$ further downstream the river enters the Gulf south of Fao city. The largest contribution in this stretch is the Karun River, which originates in Iran and enters the Shatt Al-Arab between stations 8 and 9 . It has a mean annual flow of $20 \mathrm{~km}^{3}$ and brings freshwater and sediment to the Shatt Al-Arab (Naddafi et al., 2007; FAO, 2008). The Karun has been especially subject to changes probably to influence water quantity and quality, including the construction of a series of major dams and with more planned for the tributaries. 
Table 1. Location of sampling points.

\begin{tabular}{ccc}
\hline Station & Longitude & Latitude \\
\hline 1 & $47^{\circ} 26^{\prime} 20.75^{\prime \prime} \mathrm{E}$ & $31^{\circ} 00^{\prime} 42.35^{\prime \prime} \mathrm{N}$ \\
2 & $47^{\circ} 25^{\prime} 09.32^{\prime \prime} \mathrm{E}$ & $31^{\circ} 00^{\prime} 07.00^{\prime \prime} \mathrm{N}$ \\
3 & $47^{\circ} 41^{\prime} 19.30^{\prime \prime} \mathrm{E}$ & $30^{\circ} 44^{\prime} 53.066^{\prime \prime} \mathrm{N}$ \\
4 & $47^{\circ} 46^{\prime} 27.30^{\prime \prime} \mathrm{E}$ & $30^{\circ} 34^{\prime} 34.64^{\prime \prime} \mathrm{N}$ \\
5 & $47^{\circ} 45^{\prime} 59.13^{\prime \prime} \mathrm{E}$ & $30^{\circ} 34^{\prime} 45.56^{\prime \prime} \mathrm{N}$ \\
6 & $47^{\circ} 44^{\prime} 40.88^{\prime \prime} \mathrm{E}$ & $30^{\circ} 34^{\prime} 31.25^{\prime \prime} \mathrm{N}$ \\
7 & $47^{\circ} 50^{\prime} 39.84^{\prime \prime} \mathrm{E}$ & $30^{\circ} 31^{\prime} 15.70^{\prime \prime} \mathrm{N}$ \\
8 & $48^{\circ} 00^{\prime} 49.80^{\prime \prime} \mathrm{E}$ & $30^{\circ} 27^{\prime} 44.04^{\prime \prime} \mathrm{N}$ \\
9 & $48^{\circ} 16^{\prime} 07.68^{\prime \prime} \mathrm{E}$ & $30^{\circ} 20^{\prime} 08.62^{\prime \prime} \mathrm{N}$ \\
10 & $48^{\circ} 27^{\prime} 32.77^{\prime \prime} \mathrm{E}$ & $29^{\circ} 59^{\prime} 34.91^{\prime \prime} \mathrm{N}$ \\
\hline
\end{tabular}

The width of the main river ranges from $400 \mathrm{~m}$ at Basrah to $1500 \mathrm{~m}$ at the mouth and the depth from $7.5 \mathrm{~m}$ at upstream sites to $12.5 \mathrm{~m}$ near Fao. The river is influenced by the tidal pattern in the Gulf. The tidal regime in the river is a mixed type of semi-diurnal and diurnal dominated by the semi-diurnal type with two highand two low waters occurring daily but with inequalities in heights and time of occurrence. The ebb duration is generally longer than flood duration partially due to increased water volume discharges on the ebb in comparison to the flood (Al-Ramadhan and Pastour, 1987). The river is well mixed with no significant vertical thermal stratification or vertical salinity gradient (Huq et al., 1978; Al-Mahdi et al., 2009).

Many channels are connected to both sides and these are usually used for irrigation as well as disposal of untreated wastewater. In general, the catchment area of the Shatt Al-Arab is agricultural and rural in the upstream part, whereas in the downstream it combines being densely populated with agricultural fields. Along this waterway extends the largest date palm plantation in the world, which usually benefits from the influence of semi-diurnal tidal movements for irrigation. A petroleum refinery is located on the Iranian side of the Shatt Al-Arab and there are a few industries on the Iraqi side. However, because of sanctions on Iraq and the war, industrial activities have had less impact than other sources of pollutants. Nevertheless, the pollutant load in the river increases on passing downstream due to the number of inhabitants and other activities, especially in Basrah where most of the untreated sewage disposal takes place.

\section{Materials and methods}

\section{Sample site}

Ten stations were selected (Table 1), with the first two at downstream sites on the Tigris and the Euphrates just before the formation of the Shatt Al-Arab at Qurna (Fig. 1). The other eight are on the main river, with the uppermost (station 3) of about $30 \mathrm{~km}$ downstream of the junction of the other rivers. Station 6 in Garmat Ali is close to the outflow from the Hor Al-Hammar (see above), whereas station 7 is near the centre of Basrah city.
Location of station 5 was half way between stations 6 and 4. The furthermost downstream, station 10, is subject to marked tidal movements. Stations 8 and 9 are located upstream and downstream of the inflow of Karun River, respectively. The tidal range increases from $0.5 \mathrm{~m}$ at Basrah to $3 \mathrm{~m}$ near the mouth at Fao (Fig. 1). Stations 1-6 are considered upstream sites here, whereas stations 7-10 are considered downstream.

\section{Sampling programme}

Monthly water samples were collected for chemical analysis during the period October 2009 to September 2010. Water samples were collected $20 \mathrm{~cm}$ below the surface in the middle of the river using a Van Dorn water sampler (Wildco). Sampling from all stations was started early in the morning, but upstream and downstream stations were sampled on consecutive days. The time lapses between sampling stations on a particular day would inevitably have had some effect on the spatial differences in temperature and $\mathrm{pH}$ observed at each.

\section{Sampling and analytical procedures}

Water temperature, conductivity, salinity and $\mathrm{pH}$ were measured in the field using a multi-meter (WTW, 350i), whereas turbidity was measured using microprocessor turbidity meter (Hanna Instruments, Hi 93703). Samples for laboratory use were transferred in a cool box to the Marine Science Centre and analyzed as soon as possible using methods given in APHA (1999). Water was filtered through a glass-fiber filter and the filtrate was dried in a dish to obtain values for TDS. Total hardness (indicating magnesium and calcium) was measured using the EDTA titrimetric method and bicarbonate and total alkalinity by the standard titrimetric methods for these variables. Conductivity is affected by the concentration of inorganic dissolved solids, whereas TDS is influenced both by inorganic salts and any organic matter passing through the filter.

Statistical analysis was conducted using SPSS 10. Analysis of variance was carried out among stations as well as between dates of sampling.

\section{Results}

\section{Water quality}

\section{Variables other than salinity}

All the data summarized here are given in Table 2 and the trend of variation of some selected variables at some stations is represented in Figure 2. Temperature ranged between a minimum of $15.1^{\circ} \mathrm{C}$ at station 1 in winter and $35.2^{\circ} \mathrm{C}$ at station 7 in summer. Temperature tended to be slightly lower at the three upstream sites than 
Table 2. Environmental variables (minimum-maximum) measured in the studied area.

\begin{tabular}{|c|c|c|c|c|c|c|c|c|c|}
\hline$\overline{\text { Stations }}$ & $\begin{array}{c}\text { Temperature } \\
\left({ }^{\circ} \mathrm{C}\right)\end{array}$ & $\begin{array}{c}\text { Turbidity } \\
\text { NTU }\end{array}$ & $\mathrm{pH}$ & $\begin{array}{c}\text { TDS } \\
\left(\mathrm{mg}^{-L^{-1}}\right)\end{array}$ & $\begin{array}{l}\text { Conductivity } \\
\left(\mathrm{mS} \mathrm{cm}^{-1}\right)\end{array}$ & $\begin{array}{c}\text { Total } \\
\text { hardness } \\
\left(\mathrm{mg.} \mathrm{L}^{-1}\right)\end{array}$ & $\begin{array}{c}\text { Bicarbonate } \\
\text { alkalinity } \\
\left(\mathrm{mg.L}^{-1}\right)\end{array}$ & $\begin{array}{c}\text { Total } \\
\text { alkalinity } \\
\left(\mathrm{mg.} \mathrm{L}^{-1}\right)\end{array}$ & $\begin{array}{c}\text { Salinity } \\
(\% 0)\end{array}$ \\
\hline 1 & $15.1-29.6$ & $6.8-66.0$ & $7.07-8.23$ & $789-1956$ & $1.35-1.72$ & $390-810$ & $195-341$ & $320-590$ & $0.6-1.1$ \\
\hline 2 & $15.2-29.6$ & $7.9-27.3$ & $6.6-8.33$ & $586-3120$ & $1.45-4.89$ & $430-800$ & $195-384$ & $195-384$ & $0.7-2.6$ \\
\hline 3 & $15.4-30.6$ & $7.6-21.0$ & $6.89-8.23$ & $835-2508$ & $1.73-3.84$ & $400-1000$ & $207-378$ & $340-670$ & $1.1-2.0$ \\
\hline 4 & $16.8-33.7$ & $10.9-23.4$ & $7.16-8.27$ & $1446-9982$ & $2.38-13.93$ & $440-2400$ & $207-378$ & $340-670$ & $1.5-8.1$ \\
\hline 5 & $17.3-33.9$ & $7.8-40.0$ & $7.58-8.08$ & 1465-9774 & $2.29-14.80$ & $420-2000$ & $244-378$ & $400-600$ & $1.5-8.6$ \\
\hline 6 & $16.4-33.9$ & $8.1-21.9$ & $7.31-8.28$ & 1497-6069 & $2.7-11.21$ & $480-1820$ & $280-366$ & $500-600$ & $1.6-6.3$ \\
\hline 7 & $16.6-35.2$ & $5.7-28.1$ & $6.68-8.15$ & $1632-14811$ & $3.18-20.80$ & $600-3600$ & $238-634$ & $390-660$ & $1.7-12.5$ \\
\hline 8 & $17.5-34.4$ & $4.7-23.2$ & $6.05-8.04$ & $1145-20615$ & $1.50-27.20$ & $500-3050$ & $220-402$ & $360-610$ & $1.0-16.7$ \\
\hline 9 & $17.5-33.9$ & $4.7-64.1$ & $6.75-7.98$ & $870-35524$ & $1.36-46.10$ & $370-5250$ & $256-463$ & $420-580$ & $0.8-29.9$ \\
\hline 10 & $16.7-33.4$ & $10.9-137$ & $6.75-8.65$ & $3190-42409$ & $5.6-60.20$ & $1030-7550$ & $256-536$ & $420-620$ & $3.2-40.4$ \\
\hline
\end{tabular}

further downstream, but there were no consistent differences in the rest of the river. However, seasonal differences in temperature were highly significant at all sites.

Turbidity differed significantly between stations $(F=3.9, P<0.01)$. Although higher turbidity values were recorded at station 1 on a few dates, turbidity was generally highest at station 10, where it reached 137 NTU in October 2009. Throughout most of the study period, $\mathrm{pH}$ remained alkaline. The lowest value, 6.05, occurred at station 8 in January 2010, whereas the maximum, 8.65, at station 10 in October 2009 (Fig. 2). No significant differences between sites were found, but significant differences did occur between dates $(F=9.7, P<0.01)$.

TDS showed higher values during the first 3 months of study, with a maximum of $42000 \mathrm{mg} . \mathrm{L}^{-1}$ at station $10 \mathrm{in}$ October 2009 (Fig. 2). Upstream stations showed lower TDS concentrations, with a minimum of $586 \mathrm{mg} . \mathrm{L}^{-1}$ at station 2 in December 2009. Differences between stations $(F=4.66, P<0.01)$ and dates $(F=4.17, P<0.01)$ were significant.

The lowest value for conductivity, $1.35 \mathrm{mS} . \mathrm{cm}^{-1}$, occurred at station 1 in October 2009 and highest value, $60.2 \mathrm{mS} . \mathrm{cm}^{-1}$, at station 10 on the same date (Fig. 2). Conductivity increased at most stations between October and December 2009 and then decreased and remained at lower values for that site during the rest of the study. The spatial $(F=5.5, P<0.01)$ and seasonal $(F=3.95$, $P<0.01)$ differences in conductivity were significant.

The minimum for total hardness was $260 \mathrm{mg} . \mathrm{L}^{-1}$ at station 2 in May 2010 and maximum was 7550 mg. $\mathrm{L}^{-1}$ at station 10 in October 2009 (Fig. 2). There was a trend for total hardness to increase on passing downstream, with the difference in values between downstream and upstream sites to be significant $(F=3.3, P<0.01)$. Seasonal differences in total hardness were also significant $(F=4.73$, $P<0.01)$.

Minimum values of both bicarbonate (195 mg. $\mathrm{L}^{-1}$ ) and total alkalinity $\left(320 \mathrm{mg} . \mathrm{L}^{-1}\right)$ occurred at stations 1 and 2 in November 2009, whereas maximum values of bicarbonate $\left(634 \mathrm{mg} . \mathrm{L}^{-1}\right)$ and total alkalinity (660 mg. $\mathrm{L}^{-1}$ ) occurred at station 7 in May 2010 (Table 2). Significant differences occurred between dates of sampling $(F=24.3, P<0.01)$.

\section{Salinity}

In general, salinity increased on passing downstream (Fig. 2), ranging from a minimum of $0.6 \%$, at station 1 in October 2009 to a maximum of $40.4 \%$ at station 10 in November 2009. Both spatial $(F=5.6, P<0.01)$ and seasonal $(F=3.63, P<0.01)$ differences were statistically significant.

During the last three months of the year 2009, high salinity values were found at the most upstream site (stations 3 and 4) in the main river (Fig. 2), with values of 2.0 and $8.1 \%$, respectively. The value was even more pronounced at station 6 . High salinity was also recorded at downstream station 7 during the same period of time. This increase in salinity was accompanied by low water discharge.

A correlation matrix of the measured variables at all stations and dates is given in Table 3 . The results indicate positive and significant relationships between salinity and total hardness, conductivity and TDS, whereas a negative correlation was calculated between water discharge and TDS, conductivity and salinity.

\section{Discussion}

As few studies have been reported on the features of water in the Shatt Al-Arab, some general comments will be made before considering salinity in more detail. In most cases it is only possible to speculate on the likely reasons for observations. The study was made at a time when the flow was almost certainly less than many years in the past. Total rainfall during 2009 was only $46 \mathrm{~mm}$ (Basrah Meteorlogical Station) and input from the upstream rivers into Shatt Al-Arab was much reduced. In addition, any dilution due to the Karun River was much reduced due to removal of water inside Iran. Turbidity tended to be higher at the station (1) on the lower Tigris, presumably because particles were maintained in suspension due to higher current velocities. Lower turbidity levels at station 6 than station 1 reflect increased sedimentation as water passed through Hor Al-Hammar marsh. The downstream water was less turbid during December and January, perhaps due to dilution by rain water, as reported by 

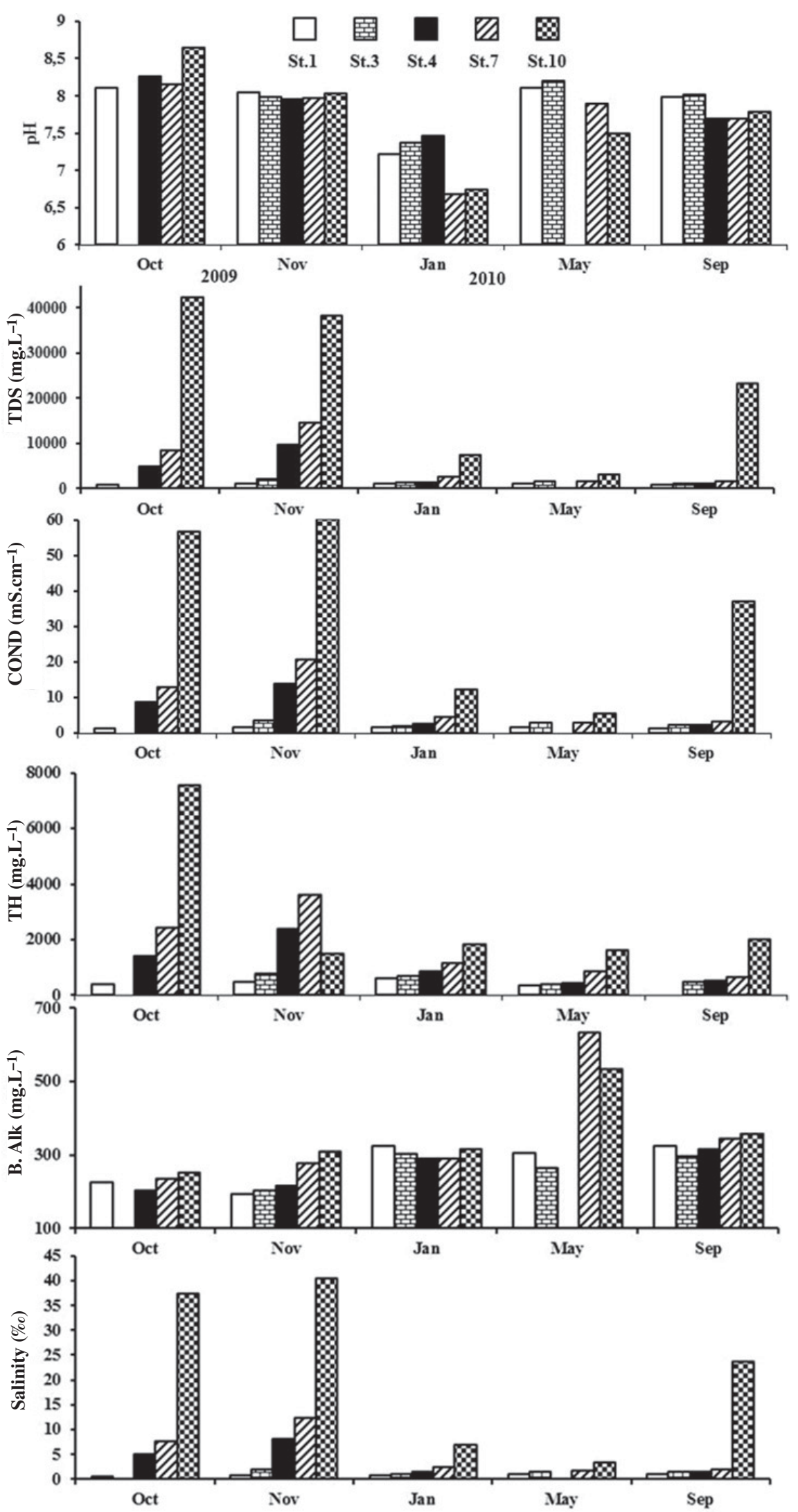

Fig. 2. Changes in physical and chemical characteristics at stations along the Shatt Al-Arab. (TDS, total dissolved solids; COND, conductivity; TH, total hardness; B.Alk, bicarbonate alkalinity). 
Table 3. Correlation matrix of the physical and chemical variables during the period of study (T, temperature; Tur, turbidity; TDS, total dissolved solids; COND, conductivity; TH, total hardness; B.Alk, bicarbonate alkalinity; T.Alk, total alkalinity; Sal, salinity; Dis, discharge).

\begin{tabular}{|c|c|c|c|c|c|c|c|c|c|c|}
\hline & $\mathrm{T}$ & Tur & $\mathrm{pH}$ & TDS & COND & $\mathrm{TH}$ & B.Alk & T.Alk & Sal & Dis \\
\hline$\overline{\mathrm{T}}$ & 1.000 & & & & & & & & & \\
\hline $\mathrm{pH}$ & $0.411^{\mathrm{a}}$ & $0.240^{\mathrm{b}}$ & 1.000 & & & & & & & \\
\hline COND & 0.035 & $0.389^{\mathrm{a}}$ & 0.113 & $0.983^{\mathrm{a}}$ & 1.000 & & & & & \\
\hline $\mathrm{TH}$ & -0.085 & $0.364^{\mathrm{a}}$ & 0.030 & $0.773^{\mathrm{a}}$ & $0.795^{\mathrm{a}}$ & 1.000 & & & & \\
\hline B.Alk & 0.157 & 0.076 & $-0.294^{\mathrm{a}}$ & -0.137 & -0.095 & -0.091 & 1.000 & & & \\
\hline Dis & 0.018 & 0.082 & 0.084 & $-0.379^{a}$ & $-0.376^{\mathrm{a}}$ & $-0.280^{\mathrm{a}}$ & $0.280^{\mathrm{a}}$ & $0.312^{\mathrm{a}}$ & $-0.363^{a}$ & 1.000 \\
\hline
\end{tabular}

Highlighted values: ${ }^{a}$ Correlation is significant at $P \leq 0.01,{ }^{\mathrm{b}}$ correlation is significant at $P \leq 0.05, n=90$.

Table 4. Reported values (minimum-maximum) for environmental variables in the studied area compared with the results of the present study.

\begin{tabular}{|c|c|c|c|c|c|c|c|}
\hline \multirow[b]{2}{*}{ Stations } & \multirow[b]{2}{*}{ Sampling dates } & \multicolumn{5}{|c|}{ Variables } & \multirow[b]{2}{*}{ Reference } \\
\hline & & $\mathrm{pH}$ & 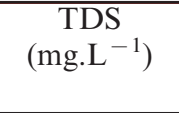 & $\begin{array}{c}\text { Total } \\
\text { hardness } \\
\left(\mathrm{mg.L}^{-1}\right)\end{array}$ & $\begin{array}{c}\text { Total } \\
\text { alkalinity } \\
\left(\mathrm{mg} . \mathrm{L}^{-1}\right)\end{array}$ & $\begin{array}{c}\text { Salinity } \\
(\% 0)\end{array}$ & \\
\hline$\overline{4,7}$ & Sep.76-May 77 & & & & & $0.74-1.04$ & (Huq et al., 1978) \\
\hline $4-10$ & April, Aug., Oct.74 & $7.46-8.2$ & & & $132-155$ & $0.29-18.9$ & (Massoud et al., 1978) \\
\hline $4-8$ & Aug.91-Aug.92 & $7.29-8.31$ & $1300-5700$ & & & $0.83-3.6$ & $\begin{array}{l}\text { (Al-Aubaidy and } \\
\text { Al-Hello, 1996) }\end{array}$ \\
\hline $4,7,8$ & Oct.97-Aug.98 & & $292-1446$ & $225-900$ & & $0.29-0.78$ & (Al-Hello, 2001) \\
\hline $4,7,8$ & Nov.02-April 04 & $7.41-8.3$ & & $461-767$ & & $0.89-2.7$ & (Al-Essa, 2004) \\
\hline $3-9$ & Jan., Feb., April 06 & $7.2-9.1$ & & & & $1.3-2.1$ & (Al-Asadi et al., 2006) \\
\hline $2,4,9$ & Summer 04-Spring 05 & $7.0-8.4$ & $440-2950$ & $270-1240$ & $94-400$ & & (Mahmood, 2008) \\
\hline $1-10$ & Oct.09-Sep.10 & $6.05-8.65$ & $586-42400$ & $260-7550$ & $320-670$ & $0.6-40.4$ & Present study \\
\hline
\end{tabular}

Yang et al. (2007) for a slow-flowing downstream stretch of the Huangpu River, near Shanghai, China. At station 10 the water became more turbid, almost certainly due to tidal currents.

The value for TDS (586 mg. $\mathrm{L}^{-1}$ ) in November 2009 at the downstream station (2) on the Euphrates contrasts with the value $\left(42000 \mathrm{mg} . \mathrm{L}^{-1}\right)$ at the mouth of the Shatt Al-Arab (station 10) at a time when the tide was high and flow was relatively low. However, high values for conductivity were recorded at both upstream and downstream stations during autumn and the beginning of winter. These results presumably reflect a combination of factors such as low rainfall, low water discharge to the main drainage system of the river (Moretto and Nogueira, 2003; Ayoade et al., 2009) and evaporation effects during summer (Boeckman and Bidwell, 2007). Similar factors may be expected to influence total hardness, which was also high during October and November 2009. The increase in total hardness on passing downstream was significant $(P<0.01)$. The hardness of water depends on dissolved salts present in water (Prasad and Patil, 2008), which was clearly shown by the significant positive relationship between hardness and TDSs in this study (Table 3).
Bicarbonate alkalinity in river system represented more than $60 \%$ of total alkalinity as has been reported elsewhere (Wetzel, 2001; Ayoade et al., 2009). Diel studies on photosynthesis are needed to interpret results such as the lower alkalinity found in April.

Except for $\mathrm{pH}$, the variables measured in the Shatt Al-Arab were higher than national and international standards for drinking water and irrigation (FAO, 1994; IQS, 2001; WHO, 2008). Although true baseline data do not exist for the river, the quality of the water suffers from contaminants loaded into the Tigris and Euphrates and from untreated anthropogenic wastes entering directly the Shatt Al-Arab through side channels. Moreover, the Mesopotamian Marshlands were well known as a natural filter for the water from the Tigris and Euphrates until this process greatly declined due to the disastrous drainage by engineers in the 1980s and 1990s. Some attempt to ascertain how water quality has changed was made by summarizing what data there are in the literature (Table 4). The question is whether salinity has also increased.

Some seasonal changes were evident in salinity and salinity was higher at the downstream stations than the upstream ones. Low salinity occurred in January 2010 


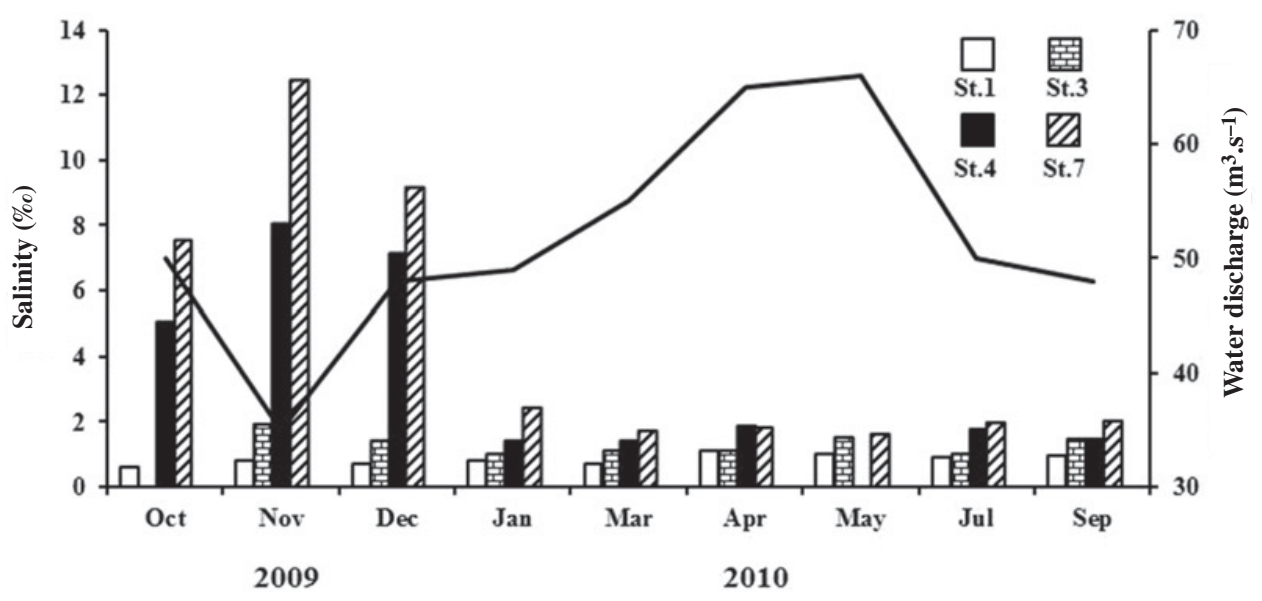

Fig. 3. Changes in water discharge and salinity at stations 1, 3, 4 and 7 during the period of study.

at all stations coinciding with low temperature and relatively high discharge, whereas the increased salinity coincided with low flows and high evaporation rates (Fig. 3). The gradual increase in salinity in the lower stretch of the river is mainly due to seawater mixing with river water during rising tides (Al-Aubaidy and Al-Hello, 1996; Yang et al., 2007). The differences between months at station 10 were largely due to the state of tidal movement when sampling was done. The values $30-40.4 \%$ o were recorded during the last 3 months of 2009, when measurements were made close to high tide, whereas values were much less $(3.2-6.9 \%$ ) during winter and spring 2010 when the measurements took place during the ebb. However, Al-Mahdi et al. (2009) reported that salinity at the same station had ranged between 0.98 and $3.9 \%$ at high and low discharge from September 1993 to August 1994. These results strongly suggest different conditions from those when our survey was conducted. Reductions in flow discharged to the river are probably the main cause, but another factor may be the higher salinity at stations close to Basrah as a result of untreated wastes entering the river system through side channels as well as agricultural run-off (Massoud, 1978; Al-Asadi et al., 2006). The impact of low water discharge is well documented by the negative and significant correlation between water discharge and salinity as well as with conductivity and TDSs (Table 3).

The influence of seawater on salinity on passing upstream is shown by the comparison of four stations in Fig. 3. The salinity value of $8.1 \%$ at station 4 in November 2009 was considerably higher than previous records. For instance, values have been recorded of $2.2 \%$ in November 2003 (Al-Essa, 2004) and 1\%o in summer 2004 (Mahmood, 2008). Salinity had reached $6.3 \%$ in December 2009 at station 6 near Hor Al-Hammar and well up the Shatt Al-Arab.

Management projects underway in the Tigris and Euphrates may lead to a water deficit in the river basin, especially during drought years (World Bank, 2006). Our study period provided an example of very low discharge, with $<50 \mathrm{~m}^{3} . \mathrm{s}^{-1}$, in the Shatt Al-Arab during the last part of 2009 (Directory of water resources in Basrah).
Such low flows will enhance seawater progression further upstream. Completion of the Ilisu Dam on the Tigris in Turkey is an important example where this is likely to have an effect. Recent and projected future changes in the Karun River system into Shatt Al-Arab are also likely to influence upstream movement of seawater in the Shatt Al-Arab (Al-Hello, 2001; Al-Asadi et al., 2006; FAO, 2008). Diversion of the Karun River towards Iranian territory caused a great reduction in flow to the Shatt Al-Arab, whereas the quality that does reach there has deteriorated because of increased salinity resulting from intensive agricultural land use and concomitant rise in saline groundwater to the surface combined with the increased impact of urban and industrial effluents (Afkhami, 2003). Construction of the Karkheh Dam on the Karkheh River and the new earth embankment on the Iranian border has greatly reduced flow into the Al-Hawizeh Marsh, with the inevitable effect of reducing flow in the Al-Suwaib stream and hence the Shatt Al-Arab (Ramsar Organization, 2010).

A few likely impacts of increased in salinity are mentioned here. The Mesopotamian marshland has just recovered from desiccation after reflooding commenced in 2003. Intrusion of seawater would undoubtedly impact the biological diversity of the marshland and the livelihood of the people there. Intrusion of seawater in the Shatt Al-Arab has made the water non-potable and caused problems for most crops. During 2009, freshwater scarcity disturbed the social stability of the area and compelled many families to migrate from impacted areas due to a decline in agricultural output and land degradation. The quality and quantity of water, war episodes in Iraq and long-term sanctions during the 1990s have greatly impaired date palm plantations and severely hit the date export industry. The livelihoods of people dependent on dates for food and income are in ruin.

The present study emphasizes the necessity for more freshwater release from the upstream countries in order to sustain the natural ecosystem of the Shatt Al-Arab and adjacent marshlands and to preserve the livelihood of the population living around the river. The need becomes 
ever clearer for comprehensive cooperation between the four countries to optimize management of the whole river basin, together with plans for water allocation and ecologically sound management. Immediate needs for the Shatt Al-Arab dilemma are the introduction of a well-planned monitoring program to safeguard the quality of the water in the river, combined with installation of treatment systems for municipal and industrial wastes, and also much improved methods for irrigation.

Acknowledgements. The work was financially supported by the Marine Science Centre, University of Basrah. The authors cordially thank Professor B. Whitton for reading and comments on a draft of the manuscript.

\section{References}

Afkhami M., 2003. Environmental effects of salinity in the Karun-Dez Basin, Iran. In: Seventh International Water Technology Conference, Egypt.

Al-Asadi M.S., Salman N.A. and Mahdi A.A., 2006. Effect of waste discharges on nutrients content and growth of Chlorella sp. from Shatt Al-Arab River. J. King Abdulaziz Univ. Mar. Sci., 17, 89-101.

Al-Aubaidy A.H.M.J. and Al-Hello A.Z.A.A., 1996. Monthly variations of the nutrients and other related factors in Shatt Al-Arab River, Basrah, Iraq. Marina Mesopotamica, 11, 365-383.

Al-Essa S.A.K., 2004. Ecological study of the aquatic plants and epiphytic algae in Shatt Al-Arab River. Ph. D. thesis, University of Basrah, $191 \mathrm{p}$.

Al-Hello A.A.Z.N., 2001. Some characters of Shatt Al-Arab River water and its suitability for different uses. Marina Mesopotamica, 16, 295-308.

Al-Mahdi A.A., Abdullah S.S. and Husain N.A., 2009. Some features of the physical oceanography in Iraqi marine water. Mesopotamian J. Mar. Sci., 24, 13-24.

Al-Mahmood H.K., 2009. The monthly variation of discharge and its effect on total dissolved solids and salinity in Shatt Al-Arab River (South of Iraq). Iraqi J. Sci., 50, 355-368.

Al-Mousawi A.H., Hadi R.A., Kassim Th.I. and Alaami A.A., 1990. A study on the algae in the Shatt Al-Arab Estuary, Southern Iraq. Marina Mesopotamica, 5, 305-323.

Al-Ramadhan B.M. and Pastour M., 1987. Tidal characteristics of Shatt Al-arab River. Marina Mesopotamica, 2, 15-28.

APHA (American Public Health Association), 1999. Standard Methods for the Examination of Water and Wastewater, 20th edn, American Water Works Association, Washington, DC.

Ayoade A.A., Agarwal N.K. and Chandola-Saklani A., 2009. Changes in physicochemical features and plankton of two regulated high altitude rivers Garhwal Himalaya, India. EJSR, 27, 77-92.

Boeckman C.J. and Bidwell J.R., 2007. Spatial and seasonal Variability in the water quality characteristics of an ephemeral wetland. Proc. Okla. Acad. Sci., 87, 45-54.

FAO (Food and Agriculture Organization of the United Nations), 1994. Water Quality for Agriculture, FAO, Rome.

FAO (Food and Agriculture Organization of the United Nations), 2003. Towards Sustainable Agricultural
Development in Iraq: The Transition from Relief, Rehabilitation and Reconstruction to Development, FAO, Rome.

FAO (Food and Agriculture Organization of the United Nations), 2007. Coping with Water Scarcity-Challenges of the Twenty-First Century, FAO, Rome.

FAO (Food and Agriculture Organization of the United Nations), 2008. Irrigation in the Middle East Region in Figures, FAO, Rome.

Fawzi I., Salman H.H. and Al-Mudaffar N., 1990. Temporal distribution of some chemical parameters of Garmat Ali River Southern Iraq. Marina Mesopotamica, 6, 251-261.

Huq M.F., Al-Saadi H.A. and Hameed H.A., 1978. Phytoplankton ecology of Shatt al-Arab River at Basrah, Iraq. Verh. Int. Verein. Limnol., 20, 1552-1556.

IQS (Iraqi Bureau for Standards), 2001. Iraqi quality standards for drinking water. IQS 417/2001.

Karim H.H., 1998. Estimation of hydrochemical characteristics of Shatt Al-Arab and southern Sadam River around Basrah area. Marina Mesopotamica, 13, 35-51.

Mahmood A.A., 2008. Concentrations of pollutants in the water, sediments and aquatic plants in some wetlands in south of Iraq. Ph.D. thesis, University of Basrah, 244 p.

Massoud A.H.S., et al., 1978. Seasonal variations of some physic-chemical conditions of Shatt Al-Arab Estuary, Iraq. Est. Coast. Mar. Sci., 6, 503-513.

Moretto E.M. and Nogueira M.G., 2003. Physical and chemical characteristics of Lavapés and Capivara rivers, tributaries of Barra Bonita Reservoir (São Paulo - Brazil). Acta Limnol. Brasiliensia, 15, 27-39.

Naddafi K., Honari H. and Ahmadi M., 2007. Water quality trend analysis for the Karoon River in Iran. Environ. Monit. Assess., 134, 305-312.

Naff T. and Hanna G., 2003. The Marshes of southern Iraq: a hydro-engineering and political profile. In: Nicholson E. and Clark P. (eds.), The Iraqi Marshlands: A Human Environmental Study, 2nd edn, Politico's Publishing, London, 169-200.

Partow H., 2001. The Mesopotamian Marshlands: Demise of an Ecosystem Early Warning and Assessment Technical Report, UNEP/DEWA/TR.01-3 Rev. 1 Division of Early Warning and Assessment, United Nations Environment Programme, Nairobi.

Prasad N.R. and Patil J.M., 2008. A study of physico-chemical parameters of Krishna River water particularly in Western Maharashtra. J. Chem., 1, 943-958.

Rahi K.A. and Halihan T., 2010. Changes in the salinity of the Euphrates River system in Iraq. Reg. Environ. Change, 10, 27-35.

Ramsar Organization, 2010. The Convention on Wetlands. Accessed online 15 July 2012. http://www.ramsar.org/pdf/ Hawizeh_MR_question_21.pdf

Wetzel R.G., 2001. Limnology, 3rd edn, Academic Press, San Diego.

WHO (World Health Organization), 2008. Guidelines for Drinking-Water Quality, World Health Organization, Geneva.

World Bank, 2006. Iraq: Country Water Resource Assistance Strategy: Addressing Major Threats to People's Livelihoods. Report No. 36297-IQ.

Yang H., Shen Z., Zhang J. and Wang W., 2007. Water quality characteristics along the course of the Huangpu River (China). J. Environ. Sci., 19, 1193-1198. 